\section{anthropology} \& materialism

\section{Anthropology \& Materialism}

A Journal of Social Research

1 | 2013

Across the Fields

\title{
Striking Dialectical Sparks from the Stones of our Cities
}

The Ernst-Thälmann-Monument in Berlin and Walter Benjamin's Materialist Methodology

Faire jaillir des étincelles dialectiques des pierres de nos villes. Le monument Ernst-Thälman à Berlin et la méthodologie matérialiste de Walter Benjamin Sacando chispas dialécticas de las piedras de nuestras ciudades. El monumento de Ernst-Thälman en Berlín y la metodología materialista de Walter Benjamin

Joanna Kusiak

\section{OpenEdition}

\section{Journals}

Electronic version

URL: http://journals.openedition.org/am/298

DOI: $10.4000 / a m .298$

ISSN: 2364-0480

Publisher:

CETCOPRA, CRASSH - Center for Research in the Arts Social Sciences and Humanities, Fakultät

Gestaltung - Universität der Künste Berlin

Electronic reference

Joanna Kusiak, «Striking Dialectical Sparks from the Stones of our Cities », Anthropology \& Materialism [Online], 1 | 2013, Online since 15 October 2013, connection on 01 May 2019. URL : http:// journals.openedition.org/am/298; DOI : 10.4000/am.298

This text was automatically generated on 1 May 2019.

Tous droits réservés 


\title{
Striking Dialectical Sparks from the Stones of our Cities
}

\author{
The Ernst-Thälmann-Monument in Berlin and Walter Benjamin's \\ Materialist Methodology \\ Faire jaillir des étincelles dialectiques des pierres de nos villes. Le monument \\ Ernst-Thälman à Berlin et la méthodologie matérialiste de Walter Benjamin \\ Sacando chispas dialécticas de las piedras de nuestras ciudades. El monumento \\ de Ernst-Thälman en Berlín y la metodología materialista de Walter Benjamin
}

Joanna Kusiak

“Pedagogic side of this undertaking: 'To educate the image-making medium within us, raising it to a stereoscopic and dimensional seeing into the depths of historical shadows'." Walter Benjamin (quoting Rudolf Borchardt)

\section{Benjamin's Magical Positivism}

Walter Benjamin's position in the field of urban studies is both very special and - on different levels - very problematic. A fascinating collection of quotations and philosophical insights into the modern metropolis, "The Arcades Project" is a unique archive, a ready-made research for those unwilling to plough through nineteenthcentury monographs on iron constructions. Alas, it is exactly because of the mosaic-like character of his work that its fragments becoming - ironically enough - nothing but ornaments on the body of some academic texts, decorating it just as art nouveau flora decorated the façade of bourgeois tenements. The more praxis and empirically oriented the city researcher is, the more probable that the speculative character of Benjamin's philosophy will either get lost or else end up as a mere theoretical appendix embellishing the empirical core. In other cases, Benjamin is historicised and systematised as a theorist of architecture. Though utterly systematic and solid, works reconstructing the figure of 
flâneur or the form and content of nineteenth-century shop windows settle Benjamin into the armchair, deeply detested by him, of "scientific complacency" (Benjamin 1999: 865 [0, 81]), from which the dialectical method should have offered escape.

The core of this problem can be found itself in the form of "The Arcades Project", which is at the same time fragmentary and comprehensive. Although the eclectic collection of quotations invites one to pull something out for one's own train of thoughts, the philosophical system of "The Arcades Project" remains coherent in spite of its cracks. Despite the numerous empty spaces in his unsystematic system, Benjamin's materialism embraces both ontology and epistemology while containing a political program descending from a strong theological background (with a very specific, Marxist-Jewish understanding of theology). "Thus, his peculiar sort of materialism does not mark a certain discipline among the other various fields of his interest (reaching from aesthetics, language and literary critique to theology and politics); rather, his materialism forms a specific approach or methodology to these fields of study." (Khatib 2010) If a sizeable chunk of so-called "Benjaminiana" cannot cope with the operationalisation of this specific, materialist methodology, it is because the latter literally blows up the limits of disciplinary categorizations, going at least one step beyond what is prevalent or admissible in any of them. Building subtle constructions out of Benjamin's epistemological notions, philosophers rarely feel obliged to give any practical tips or at least vivid examples. Yet urban theorists, digging in real urban matter with a bunch of Benjamin's quotations in mind, often seem to be strangely embarrassed with the very word "messianism" which threatens to cloud their empirical focus. With fixed methodologies, a dislike towards empirical experiments or a mere deficiency of imagination it is impossible to reach Benjamin's anthropological materialism which - as Adorno noticed - places itself "on the crossroads of magic and positivism" (Benjamin and Adorno 1994: 368).

As easy as it would be to follow one of these two paths in urban analysis, the real challenge of the anthropological materialist is to persist on the crossroads. To analyse 19 th Paris with Benjamin at one's side can foster a great deal of "scientific complacency", yet taking Benjamin to the streets of the contemporary city exposes the researcher to many other dangers. The fundamental question for those wanting to treat Benjamin according to his own philosophy ${ }^{1}$ is how to develop - without being Walter Benjamin and without pretending one is - the same kind of gaze upon contemporary cities. Years after the publication of "The Arcades Project" we too lightly pass over the fact that it is not a book but a research. A thorough one, embracing philosophical and literary fragments collected in the Bibliothèque Nationale as well as empirical observations made when walking through the streets of Paris and - last but not least - some intuitions born in the process of collecting material. There are short circuits between positivism and magic, and we can observe these in statu nascendi, watching how Benjamin tests his insights by re-writing them in slightly different versions and juxtaposing again what he had found in the library and on the street. These small-scale dialectical turns are crucial for uncovering both Benjamin's methodological instruments and his deeper philosophical interpretations. All the methodological, indeed positivist tools of Benjamin become trivial without the philosophical/theological frame of reference, whereas "the magic" of describing the city $\grave{a}$ la Benjamin without his positivist program falls into pure (better or worse) literariness. So is it possible to teach the eye to gaze dialectically? 
In my paper I will try to extract from Benjamin's urban texts some specific and usable techniques of the dialectical glance, showing both the philosophical context in which the city is for Benjamin his special object of research, and the practical, methodical dimension of his approach. The latter will be tested by looking at and analyzing a small area with a huge monument on it - the Ernst-Thälmann-Monument in Prenzlauer Berg, Berlin. Trying to reveal as many layers of decayed phantasmagoria of socialist power as possible, with the history of its urban afterlife I will also try to illustrate the philosophical-historical dimension of Benjamin's method. Referring to Denkbilder, Graeme Gilloch names this method "archeomonadological" (Gilloch 1996: 115), as it uses urban images to show the most universal dimension of the truth about the whole city, while distancing itself from building immediate theories on what exactly is seen (see also Gilloch 2002: 166). As Susan Buck-Morss observes, Benjamin's dialectical images are “[...] neither aesthetic nor arbitrary. He understood historical 'perspective' as a focus on the past that made the present, as revolutionary 'now-time', its vanishing point. He kept his eyes on this beacon, and his interpreters would do well to follow suit. Without its constant beam, they risk becoming starry-eyed by the flashes of brilliance in Benjamin's writings (or in their own), and blinded to the point" (Buck-Morss 1989: 339).

\section{The Whole of a City's DreamTimeSpace}

What is Benjamin looking at, while keeping his eyes trained on Paris (or Moscow, Berlin, Naples)? His deep fascination is for the city as a material-temporal model of reality. The famous metaphor of the Angelus Novus becomes tangible if we replace the abstract catastrophe witnessed by the terrified angel with the real city. For every city is its own ruin, both in its physical shape and in the immensity of its lost possibilities and unfulfilled fantasies (in this sense the newest skyscraper is a ruin no less than a decaying shopping arcade). In the same way that the totality of the universe expects redemption, so the true totality of the city would contain all events, all past, present and future places and spaces containing all people with all their wishes. Although such a totality is obviously an unattainable goal for every kind of earthly cognition, while looking at ruins Benjamin is always looking for its whole. Thus, his technique resembles viewing autostereograms: only if we try to look through the colorful picture into the (veiled) distance, the picture becomes three-dimensional and - instantly - its proper image emerges from the colorful chaos to float right in front of our eyes.

The city we mostly see (city-ruin) at the same time conceals its infinite whole and offers access to it. Just as the physiognomist tries to read the complexity of character out of wrinkles and facial lines, the task of a dialectician is to reach the city's whole through its materiality, which, like a face, may wonderfully lie and yet keep revealing itself through uncontrolled expressions. Despite being an attentive anthropologist, and referring directly to city's physiognomy, Benjamin never falls into the simple anthropomorphization of the city. The anthropological component serves to complement Marx's materialism, emphasizing the profoundly human (both individual and collective) character of every matter. Seizing Marx's categories of base and superstructure, Benjamin augments their subtlety, stressing the expressive character of the latter:

[...] if the infrastructure in a certain way (in the materials of thought and experience) determines the superstructure, but if such determination is not reducible to simple reflection, how is it then - entirely apart from any question 
about the originating cause - to be characterized? As its expression. The superstructure is the expression of the infrastructure. (Benjamin 1999: 392 [K2,5])

The dialectical process between base and superstructure has one more level, an even finer one which "[...] plays itself out between the collective imagination and the productive potential of the new nature that human beings have brought into being, but do not yet consciously comprehend" (Buck-Morss 1989: 124). A 19th century shopping arcade is its best illustration. Inasmuch as the analysis of means and relations of production explains the necessity of the arcade as a place of consumption, the origin of its form still remains mysterious. In the arcade's form Benjamin observes some expressive, aesthetical surplus unfolding independently of any economic cause:

I pursue the origin of the forms and mutations of the Paris arcades from their beginning to their decline, and locate this origin in the economic facts. Seen from the standpoint of causality, however (and that means considered as causes), these facts would not be primal phenomena; they become such only insofar as in their own individual development - "unfolding" might be a better term - they give rise to the whole series of the arcade's concrete historical forms, just as the leaf unfolds from itself all the riches of the empirical world of plants (Benjamin 1999: 462 $[\mathrm{N} 2 \mathrm{a}, 4])$.

8 Only a sensibility for this surplus allows us to grasp the "poetical intensity" of the historical process (see Berdet 2010a), which escapes the classical version of dialectical materialism. Concomitantly Benjamin shows that collective dreams and wish-images are not merely a mist floating above the hard base of the means of production but through their phantasmagoric materializations they are also included in the base itself, reshaping and intensifying its character. Myth is here not the opposite of matter but its inherent complement, and the modern metropolis is its modus vivendi. The whole of the city is a material Zeit $(t)$ raum ("dreamtimespace") with time, space and fantasy as the axes marking out the city's real three-dimensionality. At the same time, myth easily envelops the surface of the city, presenting this surface, over which researcher's eye is constantly shifting, as if it were a monolith. Hence the dialectician must search for cracks to destroy the fake coherence of the image with a strong-minded blow. "To the process of rescue belongs the firm, seemingly brutal grasp" (Benjamin 1999: 473 [N9a,3]).

\section{A Ruin of Socialist Berlin}

9 If the blow is to be firm, the correct clench leaves the thumb outside and never inside the palm, to prevent the fist from crushing its own thumb. Clenched exactly this way in the greeting gesture of the Red Front Fighters" League, Ernst Thälmann metal fist is itself over one meter tall. The complete bust of the pre-war German communist is fourteen meters tall and fifteen meters wide. Cast in bronze and weighing over fifty tons, the monument stands in the Berlin district of Prenzlauer Berg, in a mid-sized square at the edge of a housing estate called Ernst-Thälmann-Park. Thälmann is surrounded by a wreath of trees with four high-rise prefab buildings sticking out. Behind him a bronze flag (which we should probably imagine red) waves. 


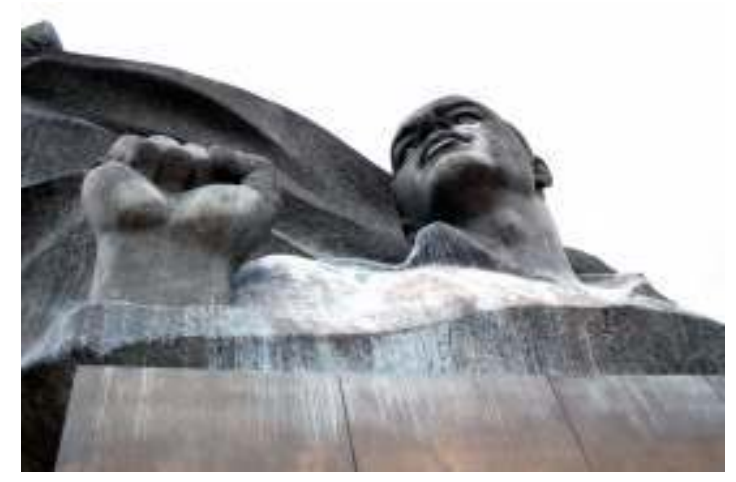

Though one of the most modern housing projects, very soon after its opening the ErnstThälmann-Park estate became a relic of the past. At the opening ceremony the communist ruling politician Erich Honecker announced: "The monument for Ernst Thälmann [...] will for all eternity announce the new chapter which has been opened with the establishment of workers" and farmers" power on the German soil" (see Monteath 2000: 191). Three years later, the chapter of history named GDR proved to be for all eternity closed. As a decadent child of its epoch, neither the estate nor monument ever reached the scale of collective emotional attention once elicited by the huge LeninMonument at Friedrichshain or the Palace of the Republic (both demolished after heated discussions). After Berlin's reunification all eyes turned toward new urban projects considered identity-shaping: Potsdamer Platz or Norman Foster's restructuring of the Reichstag. Although as a district Prenzlauer Berg attracted a lot of attention as an alternative artist quarter in the course of rapid revitalization (or, as many claimed, gentrification), Thälmann-Park remained on its margins, able neither to compete with the attractive spaciousness of old buildings nor to integrate Prenzlauer Berg's subculture in the midst of evolving from punk alternative to new-left-creative "BionadeBiedermaier", a new social class ironically named after a popular organic soda. ${ }^{2}$

Figure 2. Thälmann Park in 2011 Credit : Google Earth View

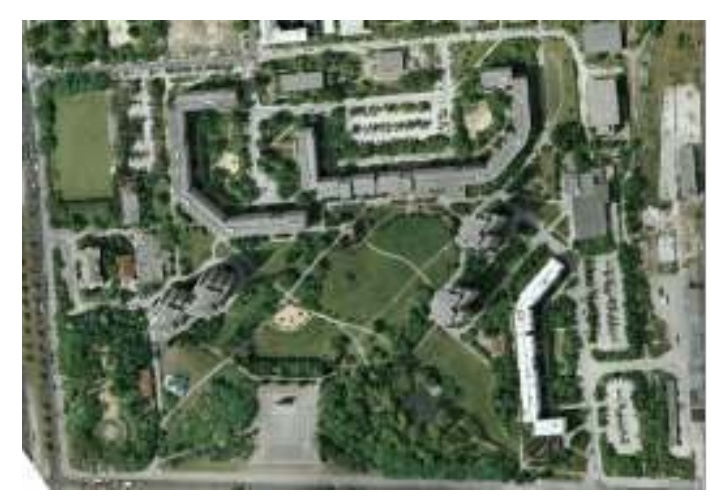

11 Both geographically and symbolically, Thälmann-Park is the borderland of new hip EastBerlin. Looking southeast, the bronze Thälmann sees the part of the district in which there are no more fancy bars but rather old corner pubs, where the apartments are cheaper and - not at all typical for the new Prenzlauer Berg - there are still old dwellers from the GDR days. On the six lanes of the loud Danziger Strasse live a lot of students. Behind Thälmann's back, in the prefab houses of Thälmann-Park, there is a mixture of 
previously prominent GDR citizens like Heinz Hoyer, the designer of the GDR-Mark and now EURO-coins, and immigrants looking for affordable housing. The pulsating city life of Prenzlauer Berg rarely enters the "E.T.-Park" (the cozy name plays on the extraterrestrial look of the monstrous statue).

This very rapid transition from the core of GDR propaganda to present day indifference gives the monument, from the perspective of Benjamin's philosophy, a very special character. Benjamin is interested mostly in second-order elements (especially those which used to be first-order) that enable us to observe the natural process of ruination taking place at a far remove from the interest of the masses. In "a certain haut-gout charm" there exists for Benjamin "[a] material of vital importance for us - not indeed for our building practice [...] but rather for our understanding, for the radioscopy [...] of the situation" (Benjamin 1999: 458 [N1,11]). The moment of decay - not the spectacular fall caused by political violence but the slow decay natural of the urban physiology - opens the way to former phantasmagorias and in some cases even to the newest urban mythologies (see also Benjamin 1999: 458 [N1,11]).

As an everyday element of the urban landscape, the ruin escapes a thorough look. Able to rapidly rouse an accidental passer-by from his or her meditations, at the same time it contributes to the drowsy atmosphere of the place. Aggressively present through its size and form, the monument remains an ordinary ruin of the GDR-past and as such an unremarkable element of the landscape. Gigantic lights once illuminating the spot are now switched off. Deprived of its ideological meaning, the monument reveals its sheer materiality. Its huge pedestal turned into a wonderful graffiti site. Besides graffiti bombing , over the Red Front inscription you can find the usual urban love declarations ("Katja, I love you!") or anything that can occur to a boy and/or girl in the mild summer night, when drinking a beer or smoking weed on a wide, sun-warmed and comfortable pedestal made of Ukrainian marble. On Thälmann you can also skate or, if you are bored, aim at his nose with cones or even with a paintball gun. During the day children play on Thälmann while their mothers sit down to have a little break. And although in 1992 an official decision about the destruction of the monument was announced, it has never been carried out. A Bavarian millionaire willing to transport Thälmann to his post-socialist monuments" collection died before the negotiations started. And for the budget of Prenzlauer Berg, blowing up the 50-ton monument proved much too expensive.

Figure 3. Playing on Thälmann. Photo: Joanna Kusiak

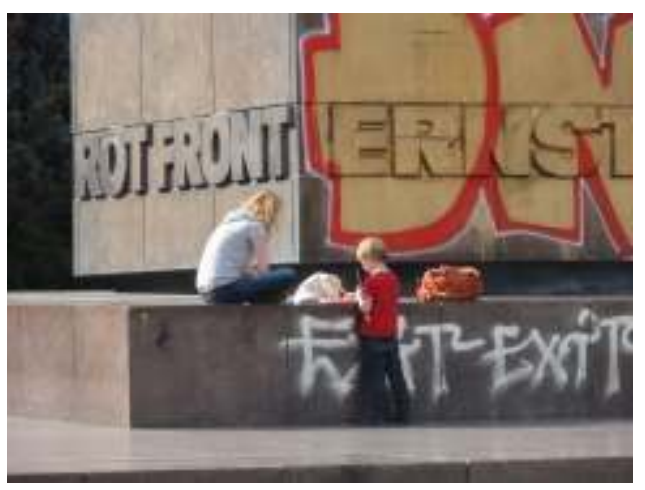




\section{The Explosion of Now-Time}

14 When in 1999 the Union of Democratic Forces of Bulgaria using 600kg of explosives tried to blow up Dimitrov's mausoleum in Sofia, the windows of surrounding government buildings were shattered into pieces and the central Batenberg Square covered itself with a thick layer of dust. The mausoleum, reinforced against nuclear attack, remained untouched. The next two trials proceeded similarly, although in the third one the amount of explosives was increased to $900 \mathrm{~kg}$. While the square looked ever worse, the mausoleum hardly teetered.

This spectacular failure of the plan to demolish the symbol of the former regime can be treated as a great lesson in Benjamin's dialectics of myth and matter. The desire for a "big bang" which would celebrate the UDF"s ultimate superiority over the (now long defeated) enemy, not only restored to the marble building (no longer containing Dimitrov's body) its whole symbolic power, but even increased it with a huge blast of explosives. The manifestation of power turned into a slapstick comedy about a clumsy tyrant, now unwittingly played by the UDF. As we can learn from Benjamin, the comic character of such a destruction results not only from the incompetence of governmental pyrotechnicians, but first and foremost from bad timing: the fully decayed ideology of communism didn't need this strong blow so its whole power hit back against present myths. If power and myth petrify into material forms which can dominate the urban landscape or at least maintain the status quo, the power to blow up this myth should also come from inside it.

Myth is for Benjamin not a simple negation of history, but its core in which the truth about the collective is stored. Architectural forms, monuments as the physiological interior of the collective "preserve this unconscious, amorphous dream configuration, they are as much natural processes as digestion, breathing [...] until the collective seizes upon them in politics and history emerges" (Benjamin 1999: 389-390 [K1,5]). Only the collective recognition of myth as myth may harness its own forces to destroy it. Hence the demolitions of monuments during the revolution of 1989 activated such a forceful collective energy.

In the psychology of the collective, myths have a similar function as dreams in the psychology of the individual. Since dream and consciousness of society are inseparable (the collective is constantly daydreaming, creating over the order of the economic base not only ideologies, but also myths and phantasmagorias), the most important elements of dialectical methodology consist in techniques of awakening. A dialectician's finest skill lies in using the very elements of the dream in order to wake up (Benjamin 1999: 464 $[\mathrm{N} 4,4])$ - that is, to recognise the dream as a dream with the elements of reality it encloses. This immanent awakening should be like "the wooden horse of the Greeks, in the Troy of dreams" (Benjamin 1999: 392 [K2,4]). A myth which has petrified into the urban landscape is the easiest to recognise at the moment of its ruination, when external noises are included in the dream's order, yet gradually become distinguishable, like the sound of worker's hammers coming from outside the window which in the dream appear as the clatter of horses" hoofs. The process of ruination is the first step towards awakening - that's why the decaying arcades held for Benjamin such a great meaning. However, the artistry of a dialectician doesn't consist solely in recognizing in ruins the fallen dreams of past generations (e.g. to recognise the mausoleum in Sofia as a symbol of 
communist myth ten years after the fall of communism), but to recognise in the way ruins undergo ruination the coming myth of one's own epoch. If, as Michelet states, "each epoch dreams the one to follow", the aim of a dialectician is not to negate an old myth but to penetrate it and to identify in it the elements of one's own mythical thinking:

Not only do you have to know well the thing you want to destroy; to complete the work of destruction you must have felt it. Or as dialectical materialism states: it is good to show the thesis and the antithesis, but only the one who recognises the point in which former turns into the latter, in which the positive collapses into the negative and the negative collapses into the positive, can intervene (Benjamin 1991: 265).

Something previously used as an alarm clock to rouse the collective from its sleep can become the strongest element of newly forming myths, while old mythical forms when entering the Now-Time can release forces able to blow up oneirical narration. Nothing is revolutionary or reactionary as such.

To destroy any monolithic structure, one needs to introduce or to find a small crack in it in order to blow it up from within. It is this Benjaminian lesson that the pyrotechnicians in Sofia learned too late. After six days of failed attempts - the same amount of time it took to build it - they finally managed to destroy the mausoleum with numerous small explosives and bulldozers smashing through cracked walls. Meanwhile, the series of failed explosions replayed on the Internet again and again, revealing very clearly the other myth, the myth of continuity, which the UDF pursued in trying to destroy the traces of the past and the myth of "the epoch of decline" where nothing from the communist past could have been saved. The Now-Time activates the energy of some historical events, while locking up others. Did anyone care or even notice how many attempts were needed to destroy the dictators" statues in 1989? Ten years after the fall of communism Bulgarian society in an opinion poll voted against the demolition of mausoleum ${ }^{3}$. The communist ideology was now harmless, yet the materiality of mausoleum released an energy subversive towards new ideologies.

All the energy needed for collective, political awakening must be the collective energy of the masses. Its source can be the "what has been", the place of its storage - the city. In any case, its trigger is always a Now-Time.

Historical materialism [...] blasts the epoch out of the reified "continuity of history." But it also explodes the homogeneity of the epoch, interspersing it with ecrasite $^{4}$ - that is, with the present (Benjamin 1999: 474 [N9a,6]).

The present is, according to Benjamin, the strongest of all explosives.

\section{The Discontents of Dialectical Shock}

If the act of looking at the city becomes too intense, this overloaded gaze can cause a reaction comparable to a short-circuiting of cognitive forces, in which a dialectical spark is produced. In the moment of such an overload a dialectical charge emerges. This spark can cause a cognitive explosion, in which the regular urban dialectical process stops for a split second like in a film frame, in the moment of the highest tension between contradictions (Dialektik im Stillstand). The Now-Time is no longer simply the present, but becomes its sudden condensation. It is a (very transient) time of multiple presents, in which the presence of the "now" as well as the presence of the "it has been" appears. A dialectical image is an intervention of the "it has been" into the chronological order of 
the city's everyday life, in which - as a freeze-frame, not a story - the complex whole of the city is revealed.

This notion of the dialectical image is fundamental to "The Arcades Project" as well as Benjamin's other city works. However, if we try to go beyond pure theory towards methodology, it's also the most troublesome aspect. Trying to translate the phenomenon of the dialectical image to the language of methodology resembles the difficulties of planning (even a secular) illumination. First and foremost, the subjectivity of the dialectical image now appears as a problem. To whom does the dialectical image appear? Between two persons standing next to each other and looking at the same point, probably only one would experience a dialectical short-circuit. And even this person would not be able to repeat this experience but only to reconstruct it using memory and thoughts. What kind of a role within methodological taxonomies can we ascribe to a phenomena that appears suddenly and not to everybody and then immediately disappears?

All the classical problems with qualitative research are here intensified: dialectical images are only weakly or not at all intersubjective, they are hard to operationalise, almost impossible to plan and - despite our best efforts - may simply fail to appear. The standstill of dialectics is the moment in which Benjamin's method jumps from positivism into magic.

Characteristically, while writing a great deal about dialectical images, Benjamin never provides us with a more detailed description of any concrete dialectical image. He points out the place and the moment of such an illumination rather than its content (see for example Benjamin 1999: 88 [C2a,10]). This is not the consequence of some methodological weakness on Benjamin's part, but derives from the non-discursive, ephemeral nature of the images themselves. A dialectical image belongs to materialist methodology on very special terms. It is neither its tool (we cannot investigate a city using dialectical images) nor its aim (the image is never what we ultimately discover). The experience of a dialectical shock is much more a moment of "switch between the circuits" [Osborne 2005: 324], the culminating point of the research, which provides the collection of fragments with a strong teleological impulse. As the source of the images comes from the monadic structure of the fragments, the dialectical method tries on the one hand to gather together as many fragments as possible and, on the other, to grasp their potential by incorporating them into experimental combinations. Exactly because the whole of the city is infinite, the dialectical researcher tries to appropriate as much of this infinity as he or she can, including in it all "the rags, the refuse" (Benjamin 1999: 450 [N1a,8]). Undertaking a research on arcades, Benjamin never differentiates between their central and peripheral elements, between their social and architectural dimension, between history and rumors, assuming that all of this belongs to the whole of the city and that even the most random elements (an iron girder, a tortoise on a leash taken on a stroll by a bourgeois lady) can prove crucial to understanding the whole.

\section{The Techniques of Seeing}

Benjamin's methodology is a methodology of excess. Even modest attempts to apply it immediately reveal why Benjamin's research project on arcades wasn't and couldn't have been finished. The dialectical methodologist is a systematic, positivistic archivist trying to compile the inventory of the city's infinity, who, when faced with this infinity, time after time switches into a surrealist visionary. From his index cards, illustrations and 
quotations he composes new assemblages only to abandon them the next moment, motivated by the sudden desire to complement his inventory with the ever-lacking element. In methodology as well as in politics Benjamin remains faithful to the principle to proceed "always radically, never consistently" (Benjamin 1997: 425-426). His perceptive and analytical experiments can be treated as dialectical études, exercises in seeing. Among them you can find (i) anthropocentric topography (Benjamin 1999: 86 $[\mathrm{C} 2,3])$ based on the meaning the objects to individuals and collectives or (ii) alternative topographies based on secondary elements like fountains, bordellos or railway stations. He also proposes to (iii) innervate the space, architecture and technology with the perspective of human experiences and fantasies, searching for the (iv) expressive surplus exceeding the merely functional or economically necessary. The procedure of (v) the compression of time in space (Benjamin 1999: 83 [C1,9]) consists in a quasi-filmic compression of movement on a chosen square or in the city in general so that the temporal distance between events is shortened or even neglected, which produces a kind of (vi) assemblage, in which the phenomena from various temporal orders clash in one spatial order. These and other kinds of assemblages inspired by the surrealists belong to Benjamin's most important techniques. The assemblages should facilitate the search for (vii) discontinuities and cracks in all historical narrations (Benjamin 1999: 474 [N9a,5]). From Bertolt Brecht Benjamin proposes to take the perspective of (viii) the city as a battlefield, concentrating on social conflicts. The technique of (ix) telescopage of "what has been" is a kind of assemblage in which events from the past are thought as a part of the present without any addition of what has happened in-between. In any event, none of these dialectical exercises can be brought to its end, in some sort of absolute knowledge. To the whole of the city Benjamin tries to get not a linear consistency but a constant change of perspective. Trying out some of these techniques on the analysis of the ErnstThälmann-Park and monument, I will try to show how different, often contradictory images can appear from such changes.

\section{Anthropocentric, Historical Topography}

On the meadows where the Ernst-Thälmann-Park sits today, a gas-works was built in 1872 , in response to the growing energy demands of the city rapidly expanding as a result of industrial revolution. This industrial artifact was thus incorporated into a previously suburban area, becoming a part of the district of Prenzlauer Berg and with that the city of Berlin. Every such widening of the city's boundaries redefines the whole of it. As a part of the urban whole, every element belongs to the urban topography and undergoes historical and social changes. To the historical-topographical research Benjamin introduces an anthropological revision, proposing "a different topography, not architectonic but anthropocentric in conception" (Benjamin 1999: 86 [C2,3]). Every topographic element of the city should be in this case analysed not only in the terms of its place, form and interplay with other elements, but also in terms of its meaning in the daily life of individuals and groups. Such a topography considers a locus in personal history no less important than the locus in time and space. The questions about place where was the gas-works? where is the Thälmann monument? - change their meaning, treating the social aspect as inherent to the order of spatial coordinates. The space becomes innervated with experience (Benjamin 1999: 631 [W7,4]). 


\section{Innervation}

Communikationsweg (today Danziger Strasse) both as a curse and a blessing. As a public plant it offered stable employment in times of crisis. On the other hand, it radically decreased the quality of life, emitting fumes, dust and soot (Soost 2001: 52-53). There were a lot of complaints about the work conditions, which became a trigger for social mobilization. Objections against twelve-hour workdays and night shifts by the coke furnace and twenty-four hour shifts on the weekends already in 1886 brought about a massive strike of the workers. As a consequence the first workers committees were created. The actively developing movement in 1905 led to the shortening of the working day to eight hours. Later, the rule of national socialists caused a radical decrease in production. Coal was essential for military purposes. At the Greifswalder Strasse site, where today the Thälmann monument stands, a high pressure gas station was built in order to fill up public buses with gas, sparing the petrol for the armament industry (see Soost 2001: 54). Many of the workers were drafted to Wehrmacht and towards the end of thirties a decision was made to pull down the gas-works and build a huge sport complex (from these plans, canceled due to the war, a football ground near to Winsstrasse remains till this day). After the war and the division of Berlin, GDR authorities decided to rebuild, extend and modernize the damaged gas-works, which, equipped with modern furnaces, kept working until 1981. However, as Soost notes (Soost 2001: 59), the effective supply of the city was possible only thanks to the creativity and personal engagement of the workers, who had to deal with a lack of resources and spare parts caused by the political situation of the GDR. In any event, the decision to close the gas-works, taken at the 10th Convention of the SED Party, met with a positive response. The dwellers of Prenzlauer Berg literally breathed a sigh of relief with slightly fresher air and, together with professional teams from Humboldt University and the Weißensee Academy of Arts began planning the reuse of the three huge gasometers, which should have remained as a material proof of the workers" history of the district. Unfortunately, soon Erich Honecker announced the decision to destroy them. The official reason given was the contamination of the soil underneath the gasometers. However, there were suspicions that the real reason was Soviet artist Lew Kerbel, who thought that the gasometers would destroy the view on his Thälmann monument (see Monteath 2000: 190). Anyway, ecological considerations were neglected due to the rush to finish the estate for Thälmann's $100^{\text {th }}$ birthday anniversary. Huge tar containers were left underground, which eventually polluted a luxurious estate containing 1336 apartments for over 4000 people, with two kindergartens, a day-care center, two playgrounds, a pond with a little waterfall, three stores, a swimming pool and (opened a year later) a planetarium. It took a great deal of effort to remove the tar afterwards, and the purification of groundwater by a small treatment plant built on the place of a moved wooden playground still hasn't been completed.

The decision to destroy the gasometers caused a massive protest which was later recognised as one of the first broad citizen movements in Prenzlauer Berg preceding the revolution of 1989. The inhabitants printed their own flyers, stickers and posters with the call "Don't demolish the gasometers" which were hung in shops as well as private windows. Thousands of letters were sent to the city council and to Honecker himself, and numerous discussions about the workers' history of the quarter were organized. 
Honecker obviously ignored all the claims of the protesters. The whole area was fenced off, photographers asked to leave and, to prevent the protesters" blockade, a couple of Stasi (secret police) members were posted inside the gasometers the night before the blasting. One of members of the SED party lost his assistant professorship at Humboldt University for taking part in the protests. At the opening ceremony Erich Honecker proudly announced: "Nothing will now recall what used to exist here, nothing will recall the odor, the bad working and living conditions, nothing will recall the assaults of Schupo (Nazi security police) and SA raids, which cost many proletarians their lives. Today proletarians are the rulers of this city, the city of Berlin, the capital city of the GDR" (after: Monteath 2000: 191). After the speech, a young pioneer-girl sung a song titled " $A$ Little White Dove of Peace".

Figure 4. Demolition of the Gasometer. Photo : Prenzlauer Berg Museum

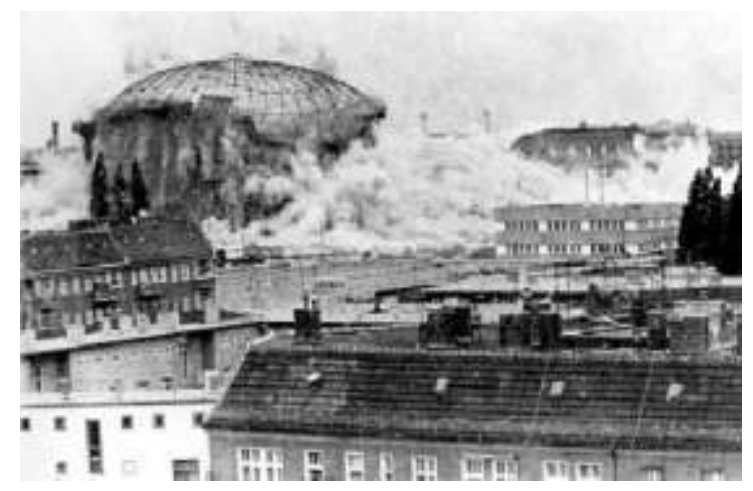

Besides the demolition of the gasometers, the project of the Thälmann monument was itself considered too aggressive. In 1982, after the publication of Kerbel's project, another wave of protests emerged. Important criticism came from East-German artists, who were frustrated that there was no public competition for the project. An especially tragic figure in this context was the sculptor Ruthild Hahne, who had been chosen to design a monument for Thälmann (in a different place) after winning a contest in 1950. For fifteen years Hahne worked on different versions of the monument, all of which were rejected. The Thälmann project ultimately destroyed Hahne's once very promising career prospects. After the final rejection in 1965 she never again received a proposal for a serious project and her first individual exhibition was not organized until she was 75 . Meanwhile, the attention given to Kerbel and the lack of any form of public competition were read as a sign of growing servility towards Moscow. What is more, the new Thälmann monument effaced the individuality of its hero, universalizing him into a pure symbol of power. Prenzlauer Berg's Thälmann received the nickname "Lehmann" because of its physiology, strangely similar to that of Lenin. Others called the monument "an enormously oversized lapel badge". There was even a letter to Erich Honecker in which a woman from Hamburg, once acquainted with Thälmann, complained that the project had nothing to do with "our Teddy", who himself "always had good contacts with the people and would never separate from them like he does in the sculpture, looking upwards" (after: Monteath 2000: 193). Soon the monument turned into one of the central knots of the GDR"s choreography of power, becoming the place for soldiers" and pioneers" nominations, marches, parades and fests, all containing a wealth of personal stories.

After the fall of the GDR, a special commission was set up to decide about the future of communist monuments. A decision was made to demolish the Thälmann monument. 
Thomas Frierl, who as a member of the SED had been formerly engaged in defending the gasometers and who now was a member of the monument commission, stated that the Thälmann monument is "a symbol of deeply undemocratic connections between politics, art and public space" (see Saunders 2010: 450). But the inhabitants were again protesting, now against the demolition of Kerbel's monument. Surprisingly, the monument won out, not due to the force of social protests but because of its monumental materiality and its dependence on - to use the Marxist term - the economic base. The decision of the commission was forwarded to the district's authorities who asserted that there was not enough money for the extremely expensive demolition of a fifty-ton monument. The monument remained at its place and deprived of its systemic legitimization, became the object of numerous conflicts.

\section{Battlefield}

31 "Cities are battlefields" - asserts Benjamin when reviewing Brecht's "Reader for a City Dweller". Brecht is for him interesting as an anti-flâneur, who never gets carried away by aesthetical fascination and always remains vigilant for social conflicts. "It's hard to imagine an observer more insensitive to the charm of a landscape than the one who was strategically trained during the battle" (Benjamin 1991: 556). Immune to the big city's overstimulation and indifferent to architectural details, Brecht is highly sensitive to the simplest signs of social relations and able to recognise in the most coherent landscape all the symptoms of underlying social struggles as well as - crucial for Benjamin's method "( $\mathrm{t}$ )he places where tradition breaks off - hence its peaks and crags, which offer footing to one who would cross over them" (Benjamin 1999: 474 [N9a,5]).

Figure 5. Figure 5. Clean Thälmann Photo: Joanna Kusiak

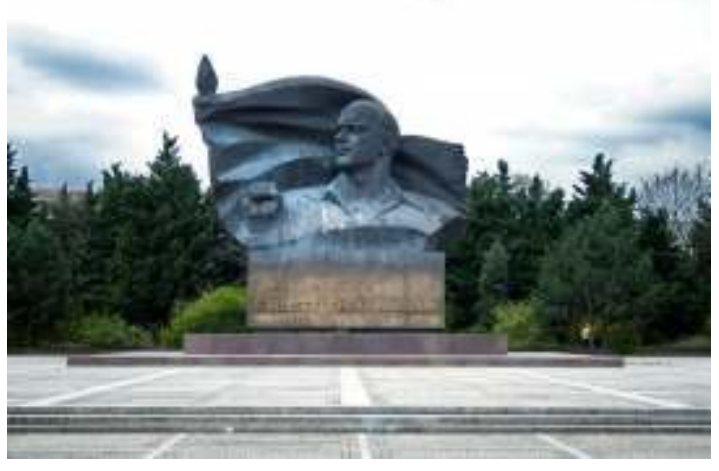




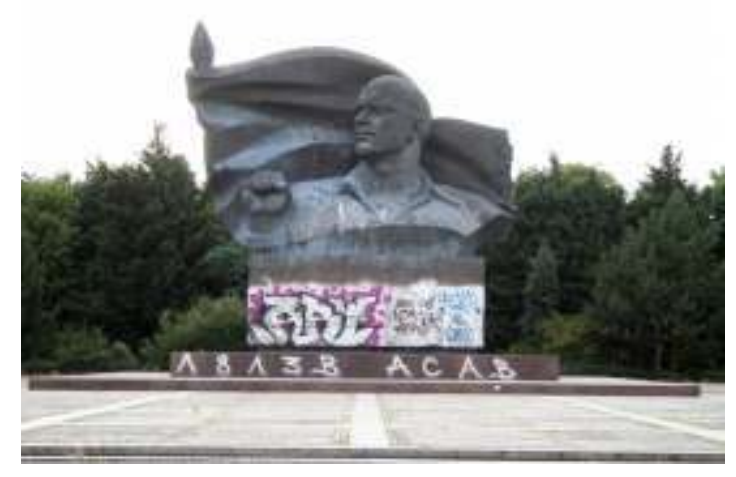

\section{Surface}

According to one of the revitalisation projects, Thälmann was supposed to be planted with Russian grapevines. Other projects proposed included a pneumatic elevator enabling the visitor to look directly into Thälmann's metal eyes, encircling the monument with a labyrinth, or converting it into fountain (BZ03/07/96). But not enough money was found for these projects. A small temporary market with regional products, initially arranged around the monument, soon disappeared. After the devaluation of ideological meaning, the monumental materiality became the dominant, functional value of the statue. Instead of an ideological figure Thälmann appeared now as a smooth, flat horizontal surface on which, partly shaded during the day by the huge head, it was pleasant to sit or even lay down with a couple of friends. It appeared as a spacious vertical surface, perfect for graffiti bombing. Moreover, a middle-size square with a couple of steps proved wonderful for the skaters.

But the ideological conflict didn't completely disappear. Over the graffiti, an inscription "Imprisoned, murdered, smeared" appeared, concerning the historical person of Ernst Thälmann, independently of its ideological use by the GDR. Max Renkl, a student from Stuttgart (and thus not burdened by the memory of the GDR) together with some young anti-Nazis as well as old "comrades" from the SED party and previously protesting city dwellers established in 2000 a Thälmann-Aktionsbündnis (TA; Thälmann Action Alliance). They decided to act against the defacement the monument, which they found unbecoming to the heroic stature of the pre-war leftist. TA tried to persuade the city authorities to clean the monument but the cost of such an action and the still standing decision to destroy it were clear arguments against the proposal. Hence, in September 2001 nearly twenty volunteers from TA, aged between 18 and 75, has spent the whole week cleaning the monument, eight hours a day, using brushes, acetone and gas burners. Flyers describing Thälmann's history were handed out. Yet a few weeks after the first cleaning action the monument was again defaced. In the beginning, members of TA tried to regularly remove new inscriptions, organizing smaller "cleaning actions" even every couple days. The surface of the monument alternated between clean and dirty. At some point, among the "usual" inscriptions swastikas and Nazi symbols appeared. In 2004 neoNazis conducted a bigger, organized "attack" after which the whole monument was covered with swastikas and skulls. Obliged to react, the police painted over them with a special paint, which unfortunately was also especially difficult for TA to remove. Finally, under pressure from TA and the swastika scandal, the district authorities decided in 2007 
to hire a private cleaning company which would clean the monument twice a year, for Thälmann's birthday and death anniversary. The monument has become one of the key local symbols of the international Antifa network, which uses it on its flyers and posters and makes it a nodal point of its annual marches. However, TA didn't manage to find a sponsor who would pay for turning on huge lights directed at the communist hero, despite the offer of hanging advertising billboards on the lamps. The city has rejected the idea of posting security guards to watch over the monument.

Figure 7. Cleaning Thälmann in April 2004. Photo: Thälmann Aktionsbündnis

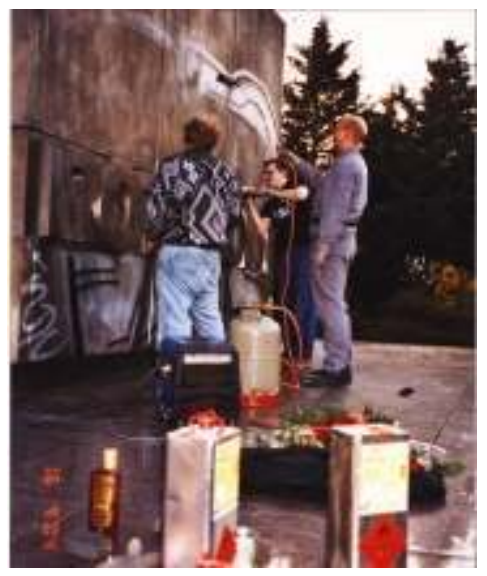

At present, the monument is defaced most of the year, with the graffitis and inscriptions changing every couple days. Twice a year, Thälmann activists organize celebrations. They gather around the monument, put out red flags and flowers, read Thälmann's old speeches and criticise capitalism. And although the composition of TA is (beyond general leftism) politically rather diverse, the post-GDR option is during these festivities most expressively present ${ }^{5}$. Afterwards, when the banners are folded up and the van from which bread and lard with pickles were sold departs, the monument again turns to a quiet and comfortable meeting place. "I met by the monument with a couple of friends to drink a tasty beer and finish off this mild Friday evening" - begins the note of the blogger Ghost Dog. Other notes will be soon written directly on the monument. The latest one, written with chalk: "Arndt, you are the adventure of my life".

Figure 8. Figure 8. Thälmann's Death Anniversary in August 2010 Photo: Joanna Kusiak

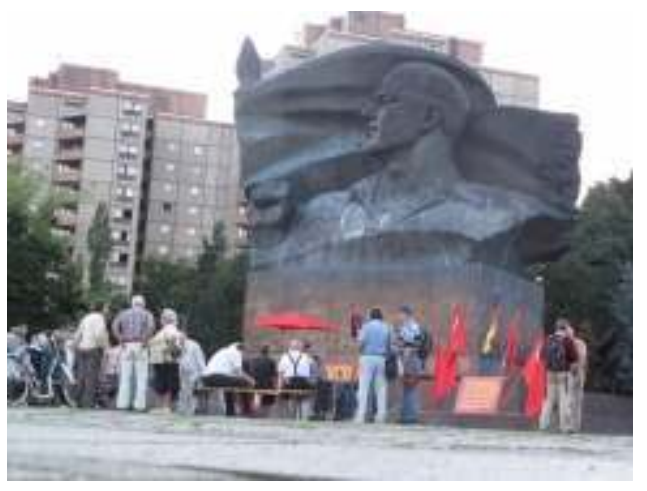


Figure 9. TA's celebration on a cleaned Thälmann in August 2010 Photo: Joanna Kusiak

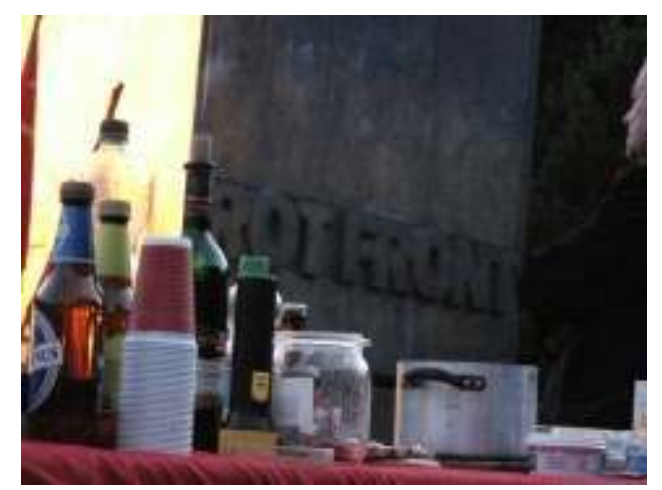

\section{Community}

"Mate Thälmann is now the mem of DKM crew, a bitchin" spot btw" - comments ElBrÖ on a web forum. DKM is one of the Berlin's graffiti teams, which numerous times "bombed" Thälmann with their signatures. The question of whether communities defining themselves as "leftist" should paint on leftist monuments again revived the war between Berlin's street art and graffiti scenes. The claim promoted by TA - "United against the right " - turned out to be just wishful thinking. Although TA activists stressed that they were not against graffiti in general, they were ever only a minor player in the real conflict between the two scenes, for which the case of Thälmann was just another catalyst. While the street art scene has a claim to embellish the public space, graffiti crews fight for the strongest presence: it's important to have the best and the most visible spot and to be brave enough to get to the forbidden or inaccessible ones. For the first the defacing of Thälmann appeared as " $a$ shame and disgrace", while the others recalled the graffiti tradition and, last but not least, the brutal form of the monument. As another DKM member states: "First, we ain't do street art like these kids thinkin they have sth to do with graffiti. Our motto is bombing till the doctor comes and I don't give a shit about a Stalinist monument. Even if this dude (Thälmann - J.K.) had a couple of good thoughts and actions, we don't paint his damn face but the pedestal. And the graffiti people always fight for sites and fame instead of trying to 'decorate the city' with self-made stickers. [...] Provo is all, street-art is nothing." Between the moralist perspective and the graffiti provocation appear some extenuating voices, which return to the critique of monument's form: "but what does it at all matter, who actually is this monstrous figure"? DKM keeps bombing. 
Figure 10. Figure 10. Resting on a Dirty Thälmann in Summer 2011 Photo: Joanna Kusiak

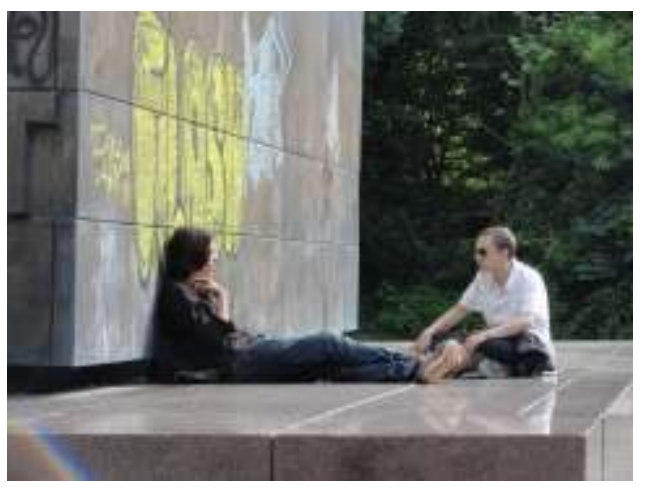

\section{Condensation of Time / Montage}

Some of Benjamin's techniques are based on (perceptive) time manipulations, disturbing the chronological time flow by, for example, speeding it up, so that the whole sequence of events appear closer together or even simultaneous. The visual or even chorographical aspect of such perception is of great importance. For Benjamin, film is the most dialectical medium, able even to "dialecticise" the perception of its viewer: "Couldn't an exciting film be made from the map of Paris? From the unfolding of its various aspects in temporal succession? From the compression of a centuries-long movement of streets, boulevards, arcades, and squares into the space of half an hour?" (Benjamin 1999: 83 $[C 1,9])$. A dialectician should be able to tune his or her perception even further, going beyond the limits of a film reel. The ultimate form of acceleration would produce a montage in which all the elements belonging to the same spatial order but to different temporal orders are put together and the most absurd combinations tried out. In his own way, Benjamin anticipates and radicalises the technique later named in anthropology as "thick description". Dialectical description would be a really "thick" one, as it thickens also the temporal orders, putting together what appears contextually separate. A rectangular plot between Greifswalder Strasse, Danziger Strasse, Ella-Kay-Strasse and SBahn track could depict the most serious and at the same time surreal scenes.

\section{Choreography of Strike}

A bunch of teenagers smoke a joint at the gas station, in the middle of which the huge Thälmann monument stands. From time to time the BVG buses stop in front of the pedestal to fill up their tanks. From the left, a group of striking gasworks workers is coming, loudly demanding the shortening of shifts. Some of them join a discussion about the workers" history of the district, immediately organized by Prenzlauer Berg inhabitants next to a pump. Everyone chants "Don't demolish the gasometers". Someone opens a beer, the other person writes with spray paint on the monument: "Don't demolish the gasometers". In the meantime, a group of East-German artists start a protest against the monumentality of Thälmann, whose gigantic fist remains raised in the same gesture as the fists of the striking workers. A woman, who turns to be Ruthild Hahne, proposes that Thälmann should be marching instead, with the raised fist, so that the striking workers can follow him. But the dwellers of Thälmann-Park are coming out of the buildings, protesting about demolishing the monument, mixing with the Antifa 
march on Greifswalder Strasse. The cries of all protesters merge in one loud and incoherent cry. Suddenly, in the middle of the gas station a pioneer-girl wearing a sootdirty white shirt starts singing "A little white dove of peace".

\section{Choreography of Purification}

The air smells of soot, tar and coal. The gasometer explodes, raising dust and rubble. The air gradually clears. The dwellers of Prenzlauer Berg breathe a sigh of relief, although the tar containers remain underground. In the groundwater a specialist discover cyanides and phenols. The air smells badly again. The pumps keep cleaning the water. The graffitists keep defacing the monument. The chemical cleanser "Chemistrip", bought by TA activists, turns out to be toxic. TA cleans the monument using acetone and gas burners. The air in the bar "Under the gas lamp" in Thälmann-Park starts to smell like gas. Teenagers write something on the pedestal. TA cleans the monument. A DKM crew bombs the monument. TA cleans the monument. A teenager writes a love declaration on the monument. Neo-Nazis paint some swastikas on Thälmann's head. Honecker gives a speech in front of the defaced monument. Neo-Nazis paint swastikas on Honecker's head. Police blot out the swastikas with special paint. TA has problems removing the police's paint from Honecker's head. A private cleaning company paid by the city cleans Honecker as well as the monument. TA proposes to turn the lights on. The monument is dirty. Graffiti on the monument keep changing like shifting patterns in a kaleidoscope. TA cleans the monument with the brushes for hours. Except for graffiti, it's covered with the gasworks' soot.

\section{Positivist Messianism}

All Benjamin's techniques have one aim: "to churn one's brain in order to produce astonishment" (Benjamin 1999: 295 [J37,2]), according to the expression of Leconte de Lisle quoted by Benjamin. Everyone expecting from Benjamin more "scientifical conclusions" has to be disappointed. As Berdet states, Benjamin's method is more "a sensibility, that grasps a playful doing in action", offering "a metonymy of a historic kernel that cannot be symbolised immediately without losing its specificity" (Berdet 2010a). The more bravely we build the assemblages, the quicker "scientific complacency" falls apart together with all its initially coherent narrations. In the case of ErnstThälmann-Denkmal everything appears ambiguous and incoherent: the historical figure of Thälmann, the way it's used by GDR propaganda, the history of the workers and dwellers of Prenzlauer Berg, the monument project prepared by Ruthild Hahne and the one designed by Lew Kerbel, the idea of its demolition, the positions of the main parties towards it, the actions of Thälmann Aktionsbündnis and the internal divisions of Berlin's left scene. The coherence of every single narration can be easily ruined by combining it with the rest of them.

Being a vanished phantasmagoria of power, as a ruin Thälmann's monument transformed into a strictly anti-phantasmagoric place. If a phantasmagoria is "a false synthesis of all social contradictions" and "a false synthesis of the past and the present" (Berdet 2011b), the monument, maintaining the dynamics of conflict on its surface, does not allow any such synthesis. While city authorities and advertising campaigns are busy presenting the modernity and progress of a unified Berlin, the monument proves to be a broken record. 
As opposed to the city's new identity projects like Potsdamer Platz, which pretend all social and political divisions are now abolished, the huge, twelve-meter high Thälmann, keeps returning to the initial point of transformation. The eternal return of smearing and cleaning, better than the most refined critical art projects, compels one to rethink all positions. Years after, neither the monument's demolition nor its protection by security guards seems possible. And as neither of Thälmann's material states (dirty/clean) is fixed, interpretation can be never closed and the next stage never begins. Unexpectedly enough, together with the narration about unification and progress, the case of Thälmann destroys the narrative of the unity of Berlin's left. A history - even a leftist history - is always "written by the winners", even if victory means nothing more than material subsistence. The presence of the Thälmann monument, independently of all controversies, has dimmed the history of the destroyed gasometers.

41 The surface of the monument presents us not with the standstill but the looping of dialectics: from the perspective of the whole Berlin, the monument is a dialectical loop which does not allow the dialectical-historical process to arrive at the next step. If the dialectical image is a subjectively mediated, momentary standstill of the dialectical process, the dialectical loop is more an internal error of the system itself. Because of it, instead of moving forward the dialectical process keeps returning to the same point. This allows all the internal systemic contradictions to act out again and again, increasing the possibility of a radical clash with the (given) Now-Time in which a dialectical image would appear to destroy one or many of the dominating narrations. The replay mode of the monument's existence allows its different states to enter the ever-new Now-Time, testing its dialectical possibilities.

In his methodological approach, Benjamin shows both the essentiality of positivism and its discontents. The main trick here is trying to grasp always slightly more than it's actually possible to grasp. This is reached through the constant mixing of perspectives, in which a city unveils its porosity ${ }^{6}$ the interpenetration of material, social-political and fantastic-mythical dimensions. As opposed to most of the classical methodologies, Benjamin does not escape this porosity but makes use of its potential, trying to reach the whole through the monad of fragment. By doing so, he is not afraid of contaminating the real with fantasy, convinced that fantasy is an equal element of the city's real. Also, he also concentrates on the moments of transition between material and social, real and fantasy, myth and its ruination, convinced that if we cannot grasp the whole directly as a static object, we can still try to grasp the totality by seizing its dynamics in the moment of Now-Time. In this dynamics, neither the city nor the society in a wider sense proves to be linear - the linear classification of events is at the most the starting point of the real research, in which the whole is to be perceived not from the perspective of but within a Now-Time.

Nevertheless, the dialectical techniques of perception do not offer the ultimate result of the research. "In the fields with which we are concerned, knowledge comes only in lightning flashes. The text is the long roll of thunder that follows." (Benjamin 1999: 456 [N1,1]). Benjamin's methodology is a methodology of seeing, and not one of writing scientific reports. What is to be seen is "a specific critical point" in the internal movement of the city's whole, mediated by dialectical images (Benjamin 1999: 463 [N3,1]). From the point of view of scientific praxis, the negative, destructive aspect of this method is much easier to grasp whereas the positive aspect can easily get lost in the implicit linearity of the scientific text. The challenge of making the next step (which, in case of 
The Arcades Project, Benjamin never had a chance to complete) would be to remain scientific without imposing a typical scientific consistency, which too often closes the city's dialectical infinity.

One of the most important openings mediated by Benjamin's work is the politicalmessianic one. From the contradiction between the incompleteness of a ruin and the flash that unveils the whole an impulse to political action is born, directed both into the past and into the future (or, in messianic terms, into the future of every past). Here again magic and positivism clash: the "magic" moment of revolutionary action in the city should be followed by the "positivist" task of redemption. The secular power of such messianic positivism comes from the "weak messianism" mentioned by Benjamin in "On the Concept of History". It is based on the pursuit of happiness which, acted out by every individual and every generation of inhabitants, charges the city with revolutionary potential: "In its spatial but also in its temporal totality, the rhythm of Messianic nature, is happiness." (Benjamin 1986: 312). The workers" strike at the gasworks as well as the pride of a young pioneer honored in front of the Thälmann-Monument, the hope for better living conditions of Prenzlauer Berg dwellers as well as the failed artistic creation of Ruthild Hahne, the graffitist striving for fame as well as a teenager's memories of a date on Thälmann should all -according to Benjamin - undergo not only a process of critical destruction of their context, but also a positive archeology of the happiness lost in the historical process. The political task of the dialectician would be to destroy the very idea of "decline" by freeing hopes and expectations buried by the ruins and re-injecting their positive energy into the order of the contemporary city. And this task is a positivist one, similar to the task of Cinderella, separating the peas from the ashes:

Modest methodological proposal for the cultural-historical dialectic. It is very easy to establish oppositions, according to determinate points of view, within the various "fields" of any epoch, such that on one side lies the "productive," "forwardlooking," "lively," "positive" pan of the epoch, and on the other side the abortive, retrograde, and obsolescent. The very contours of the positive element will appear distinctly only insofar as this element is set off against the negative. On the other hand, every negation has its value solely as background for the delineation of the lively, the positive. It is therefore of decisive importance that a new partition be applied to this initially excluded, negative component so that, by a displacement of the angle of vision (but not of the criteria!), a positive element emerges anew in it too-something different from that previously signified. And so on, ad infinitum, until the entire past is brought into the present in a historical apocatastasis (Benjamin 1999: 463 [N 1a, 3]).

\section{BIBLIOGRAPHY}

Beyond the positivist madness of this in infinitum, remains for the researcher the arduous striking of dialectical sparks.

Benjamin, A. 1994. Walter Benjamin's Philosophy: Destruction and Experience. (ed.) Osborne, Peter. London: Routledge. 
Benjamin, W. 1986. Reflections: Essays, Aphorisms, Autobiographical Writings. (tr.) E. Jephcott. New York: Schocken Books.

Benjamin, W. 1991. Gesammelte Schriften. Frankfurt am Main: Suhrkamp.

Benjamin, W. 1997. Gesammelte Briefe. t. I-VII. Frankfurt am Main: Suhrkamp.

Benjamin, W. 1999. The Arcades Project. (tr.) H. Eiland and K. McLaughlin. London: The Belknap Press of Harvard University Press.

Benjamin, W. and Adorno T. 1994. Briefwechsel Adorno-Benjamin 1928-1940. Frankfurt: Suhrkamp.

Berdet, M. 2010a. What is Anthropological Materialism? Accessed on 01 May 2011. URL: http://

anthropologicalmaterialism.hypotheses.org/644

Berdet, M. 2010b. Eight Thesis on Phantasmagoria. Accessed on 01 May 2011. URL: http://

anthropologicalmaterialism.hypotheses.org/611

Berliner putzen Thälmann. 2002. Berliner Kurier. October 18th.

Buck-Morss, S. 1989. The Dialectics of Seeing: Walter Benjamin and the Arcades Project. London: The MIT Press.

Denkmal von Graffiti befreit. 2001. Berliner Zeitung. September 22nd-23rd.

Eine Dusche für Ernst Thälmann. 2000. Neues Deutschland. October 27th.

GhostDog. Accessed on 10 June 2011. URL: http://ghostdog19.wordpress.com/2007/04/14/einenacht-bei-ernst-thalmann/

Gilloch, G. 1996. Myth \& Metropolis: Walter Benjamin and The City. Cambridge: Polity Press.

Gilloch, G. 2002. Benjamin's Moscow, Baudrillard's America. In The Hieroglyphics of Space: Reading and Experiencing the Modern Metropolis. (ed.) Leach, Neil. London and New York: Routledge.

Graffiti-Angriffe. Braucht Thälmann Polizei-Schutz? 2007. Berliner Kurier. January 17th.

Heiße Luft gegen Schmierereien. 2003. Berliner Morgenpost. August 16th.

Khatib, S. 2010. Karl Marx, Walter Benjamin and the Spectre of the Messianic: is there a Materialist Theory of Time? Accessed on 01 May 2011. URL: http://

anthropologicalmaterialism.hypotheses.org/844

Lilapapierschwein. Accessed on 10 December 2010. URL: http://

lilapapierschwein.blogsport.de/2007/08/02/1944-ermordet-seit-dem-immer-wiedergeschaendet-rotfront/

Monteath, P. (ed.). 2000. Ernst Thälmann. Mensch und Mythos. Amsterdam: Rodopi.

Osborne, P. 2005. Quasi-messianic interruption. In Osborne P. Walter Benjamin: Critical Evaluations in Cultural Theory. Vol. 1. New York: Routledge, 318-333.

Pseudosozialisten die Stirn bieten. 2007. Neues Deutschland. April 16th.

Saunders, A. 2010. The Ghosts of Lenin, Thälmann and Marx in the Post-Socialist Cityscape. German Life and Letters 63:4. October 2010. URL: http://onlinelibrary.wiley.com/doi/10.1111/ j.1468-0483.2010.01509.x/abstract

Schnecke oder Thälmann. 1994. Varianten für das Denkmal an der Greifswalder Straße werden jetzt diskutiert. Berliner Zeitung. January 29th.

Soll das Thälmann-Denkmal abgerissen werden? 2003. Berliner Kurier. July 11th.

Soost, H. 2001. Gas und Koks, Ruß und Staub. Berlinische Monatsschrift, $\mathrm{n}^{\circ} 4$. 
Thälmann in Prenzlberg vergessen! 2008. Abriss schon seit 15 Jahren beschlossen. Bild. November 11th.

Thälmann soll wieder glänzen. 2001. Tageszeitung. October 17th.

Verbaler Dreck. 2001. Neues Deutschland. July 11th.

Wieder vorzeigbar. 2001. „Aktionsbündinis” säubert das Ernst-Thälmann-Denkmal. Tagesspiegel. September 22nd.

\section{NOTES}

1. Which would mean making real use of his work, pulling it into our own historical perspective: "It is said that the dialectical method consists in doing justice each time to the concrete historical situation of its object. But that is not enough. For it is just as much a matter of doing justice to the concrete historical situation of the interest taken in the object." Benjamin 1999: 391-392 [K2, 3]

2. http://www.zeit.de/2007/46/D18-PrenzlauerBerg-46

3. see: http://news.bbc.co.uk/2/hi/europe/431854.stm

4. In the English translation the word "ecrasite" has been replaced with the word "ruin". I refer here to the German original.

5. I base here on the commemoration I took part in on 2010, August 20th.

6. The concept of porosity was developed by Benjamin together with Asja Lacis in an essay on Naples.

\section{ABSTRACTS}

In his methodology as well as his political thought Benjamin remains faithful to the principle to proceed "always radically, never consistently". Therefore, the greatest challenge for a contemporary city researcher inspired by Benjamin is to operationalise his materialist methodology. Benjamin's anthropological materialism cannot be reached within the fixed limits of any discipline, but rather places itself "on the crossroads of magic and positivism" (Adorno); the dialectical image is not a tool of his methodology but its culminating point where positivism turns to magic. To reach this point, Benjamin conducts perceptive and analytical experiments that can be treated as dialectical études, exercises in seeing. The paper examines some of these techniques, exploring their philosophical context and testing them on a contemporary example: the Ernst-Thälmann-Monument in Berlin.

En su metodología, así como en su pensamiento político, Benjamin es fiel al principio de proceder «siempre radicalmente, nunca sistemáticamente». En este sentido, el mayor desafío para un investigador de la urbe contemporánea inspirado en Benjamin es de hacer operatoria su metodología materialista. El materialismo antropológico de Benjamin no se presenta a sí mismo en los límites fijos de cualquier disciplina, sino más bien «en el cruce de la magia con el positivismo" (Adorno); y la imagen dialéctica no es tampoco una herramienta de su metodología, sino el punto culminante en el que el positivismo se hace magia. Para alcanzar este 
punto, Benjamin expone experimentos de percepción y de análisis que pueden ser tratados como études dialécticos, ejercicios de la visión. El presente artículo examina algunas de esas técnicas, explorando su contexto filosófico y poniéndolas a prueba en un ejemplo contemporáneo: el monumento de Ernst-Thälmann en Berlín.

Dans sa méthodologie comme dans sa pensée politique, Benjamin reste fidèle au principe de rester «toujours radical, jamais conséquent». Le plus grand défit pour un chercheur sur la ville aujourd'hui inspiré par Benjamin est alors de rendre sa méthodologie matérialiste opérationnelle. Son matérialisme anthropologique ne tient pas dans les strictes limites d'une quelconque discipline, mais se situe plutôt "au croisement de la magie et du positivisme » (Adorno). L'image dialectique n'est pas l'instrument de sa méthode, mais son point culminant, là où le positivisme se retourne en magie. Pour atteindre ce point, Benjamin mène une suite d'expériences sensibles et analytiques que l'on peut concevoir comme des études dialectiques, des exercices de la vision. L'article examine certaines de ces techniques, explore leur contexte philosophique et les teste sur un exemple contemporain : le monument Ernst Thälmann à Berlin.

\section{INDEX}

Keywords: anthropological materialism, materialist methodology, Benjamin Walter, dialectical seeing, city

Mots-clés: matérialisme anthropologique, méthodologie matérialiste, Benjamin (Walter), vision dialectique, ville

Palabras claves: materialismo antropológico, metodología materialista, Benjamin Walter, visión dialéctica, ciudad

\section{AUTHOR}

\section{JOANNA KUSIAK}

University of Warsaw / Technische Universität Darmstadt 